This item was submitted to Loughborough's Research Repository by the author.

Items in Figshare are protected by copyright, with all rights reserved, unless otherwise indicated.

\title{
Global sport and consumer culture: An introduction
}

PLEASE CITE THE PUBLISHED VERSION

https://doi.org/10.1177/1469540517744691

\section{PUBLISHER}

(c) The authors. Published by SAGE Publications Ltd

\section{VERSION}

AM (Accepted Manuscript)

\section{PUBLISHER STATEMENT}

This work is made available according to the conditions of the Creative Commons Attribution-NonCommercialNoDerivatives 4.0 International (CC BY-NC-ND 4.0) licence. Full details of this licence are available at: https://creativecommons.org/licenses/by-nc-nd/4.0/

\section{LICENCE}

CC BY-NC-ND 4.0

\section{REPOSITORY RECORD}

Giulianotti, Richard, and Dino Numerato. 2019. "Global Sport and Consumer Culture: An Introduction". figshare. https://hdl.handle.net/2134/31899. 


\section{Global Sport and Consumer Culture:}

\section{An Introduction}

\section{Richard Giulianotti and Dino Numerato}

This special issue of the Journal of Consumer Culture investigates the complex intersections of global sport and consumer culture. Our aims in putting together this issue have been interrelated and twofold. First, most importantly, we have sought to open up new knowledge and critical understanding of the underexplored nexus of consumer culture and global sport. In doing so, second, we have endeavoured to facilitate a critical and comparative grasp of this relationship, by providing studies of different sport and consumer cultures in diverse national and transnational contexts, and by drawing on a wide range of social scientific disciplines and standpoints.

Thus, the special issue features seven papers on global sport and consumer culture that have disciplinary moorings in sociology, anthropology, history, management and marketing studies, and cultural studies, and which harness research from Europe, East and South Asia, North America, and Australasia. Our contributors utilize studies and illustrations from many sporting domains, notably baseball, cricket, football, Olympic sports, and e-sports.

A quick glance at contemporary global sport attests to its multifarious ties to consumer culture. Sport fans follow clubs and athletes across local, national, and, increasingly transnational levels, and display these allegiances in part through branded sport merchandise. Global consumer culture is increasingly populated by baseball caps, training shoes, $\mathrm{t}$-shirts with team logos, and other sport-related consumer products. A burgeoning transnational fitness industry promises to sculpt the idealized consumer body, on which these products are to be worn, and on which self-tracking exercise devices are to be appended (Lupton 2016; Sassatelli 2004). Advertising and endorsements for consumer products feature prominent inputs from global sport stars, clubs and governing bodies (Horne, 2006; Smart, 2005). Sport fans now access vast volumes of top-level sports, which are wrapped in corporate advertising, and screened worldwide on commercial television and digital platforms (Hutchins and Rowe, 2012). Powerful corporate interests drive the founding and global spread of glamorous sport events and tournaments - from the Olympic Games and football's World Cup finals, through to numerous 'national' leagues - that are marketed to fast-consuming urban middle-classes (Giulianotti, 2015). Yet, these commercial processes are not uncontested, but instead 
germinate unease, criticism and protest over the influence of capital on how sport is experienced, played and organized (Lupton, 2016; Walsh and Giulianotti, 2007).

These and many other intersections of consumer culture and global sport provide the focus for this special issue. Our introduction has three main parts. First, we set out the extensive historical ties that exist between global sport and consumer culture through a three-phase model of the relationship. Second, we detail the large-scale social processes that underpin global consumer sport, and the major substantive social themes that emerge from the papers herein. Finally, we outline the paper-by-paper contents of the special issue.

\section{Historical Aspects: Global Sport/Consumer Culture 1.0, 2.0, 3.0}

The connections between global sport and consumer culture are not new, but instead are extensive and long-standing. We contend that global sport and consumer culture have passed through three historical phases of globalization, which are named here as Global Sport/Consumer Culture 1.0, 2.0, and 3.0, respectively. The phases represent a version of Robertson's (1992) multi-phase model of globalization, which we have adapted in part to account for the specific aspects of consumer culture within transnational sport. ${ }^{1}$

1) Global Sport/Consumer Culture 1.0: this represented a take-off phase of global consumer sport from the late $19^{\text {th }}$ century to mid-1940s. In this period, there was a formal standardization of most modern sports, such as the various football codes ('soccer', rugby union, rugby league, American football, Australian rules football), and many Olympic disciplines. Most sports also underwent long-term diffusion across different parts of the world, with several (notably the football codes) gaining mass popularity. At the same time, mass consumer culture took off in industrialized and industrializing urban centres, in the forms of fashion, cinema, cuisine, music, dance, automobiles, and popular media, in the pursuit of idealized consumerist lifestyles. Sport's ties with consumer culture were located mainly at elite level: sport clubs charged spectator admission, enabling the professionalization of athletes in most sports; major events attracted coverage in the commercial mass media and early product advertising; and, the most popular local and national male, white athletes endorsed consumer products.

2) Global Sport/Consumer Culture 2.0: this constituted an integrative and expansionist phase in most non-Communist developed nations during the Cold War era (late 1940s 
through to the late 1980s). Male professional sport was positioned within a panoply of Fordist leisure industries in entertainment, tourism, and general recreation. Sport grew links also to commercialized youth and popular culture, notably in fashion and music, with leading sport stars - still almost always male and white - being engaged in product endorsement and displays of conspicuous consumption. Sport was more assiduously covered in the mass media, notably television; sport events were increasingly constructed as consumer experiences; and, global merchandise corporations such as Adidas, Reebok and Nike were founded and gained commercial footholds. Latterly, sport qua physical activity and lifestyle realm was deeply embedded in late-capitalist consumer identities, notably through the fitness industries and heavily branded alternative sports. Finally, media development, deregulation and globalization in the late 1980s provided important bases for major commercial transformations of global sport in the next phase.

3) Global Sport/Consumer Culture 3.0: this has featured an ongoing transnational hypercommodification phase since the early 1990s, as ties between global sport and consumer culture have acquired a greater level of intensity and complexity. Key aspects of the globalization of the sport economy include greater transnational sports markets for elite athletes; global production and consumption chains for sports merchandise; commercial partnerships between elite sport 'brands' (clubs, leagues, federations, athletes) and transnational corporations; the burgeoning value of television contracts for top-level sport; and, in broad terms, the rapidly growing commercial scales and incomes of top leagues, clubs and athletes. Global consumer sport presents as more open to rapidly growing and hitherto overlooked markets, notably women, ethnic minorities, and populations from outside the global North. Economic, social and political divisions have intensified between different leagues, clubs, athletes and sport communities. At the same time, alternative sports and esports have developed, and have been commercially incorporated into the existing global sport industries. Meanwhile, accelerated development and globalization in Asia, Latin America and Africa have opened up some possibilities for creating heavily commercialized sport tournaments outside of the global North (e.g. Brazil 2014 and Qatar 2022 World Cup Finals, Indian Premier League cricket). ${ }^{2}$

These three broad historical periods provide an analytical framework for tracking and grasping major developments across global consumer sport. Like any other attempt at 
historical periodization, we are sure to find specific issues and areas of social life which cross between the different periods or phases. One such case is provided by how the meaning of 'sport' has expanded, particularly with reference to consumer culture. In phase 1.0, sport was more firmly associated with a fixed set of codified, competitive, and corporeal disciplines. Where it had wider application, in Britain and much of the colonies, 'sport' may also have been associated with old pastimes such as fox-hunting and shooting that were linked to upperclass countryside pursuits (Huggins, 2008). In phases 2.0 and, in particular, 3.0, the expanded meanings of 'sport' have been more associated with a wider array of physical practices and cultures that have close ties to 'lifestyle' consumer culture, such as the fitness industries and 'alternative' sports (e.g. surfing, snowboarding, and skateboarding) that have mushroomed since the 1970s, and been remorselessly commercialized by global fashion brands such as Quicksilver, Billabong, Rip Curl, and Hollister (Crawford 2004; Horne 2006; Stranger 2017; Wheaton and Beal 2003). This commercialization was simultaneously accompanied by the incorporation of the so-called X-games into the Olympic movement and industry (Thorpe and Wheaton, 2011).

\section{Global Consumer Sport: Large-Scale Processes and Substantive Themes}

We turn now to set out the large-scale processes and substantive themes that shape the interrelations of global sport and consumer culture. The large-scale processes refer to major transnational developments that underpin global sport, consumer culture, and many other fields of modern life. The substantive themes relate to those particular aspects of social life that are identifiable within global consumer sport, and which emerge in different ways in the contributions to this special issue.

\section{Large-Scale Processes}

Here, we identify five deep and interlocking large-scale transnational processes that undergird global consumer sport. These 'ization' processes are discussed in our paper for this special issue, and may be summarized as follows:

- Globalization, marked by a growing array of transnational connections and greater consciousness of the world as a single place (Robertson, 1992);

- Commodification, which involves turning people, services, ideas, and objects into 'commodities' with potential or actual market values (Walsh and Giulianotti, 2007); 
- Securitization, characterized by the surveillance and social control of different populations and social spaces, often with advanced technologies (Giulianotti and Klauser, 2009);

- Mediatization, registering the expanding everyday prevalence and influence of the mass and social media (Boyle and Haynes, 2009);

- Postmodernization, featuring critical social changes, such as the blurring of modern boundaries and categories (e.g. between classes, genders, ethnic groups; also spatially and temporally), and the growing social influence of the virtual, mediatized world and e-sports (Jenny et al., 2017; Witkowski, 2012).

In the global sport and consumer culture context, one powerful illustration of these processes is provided by world-leading sport leagues, which are played in heavily securitized stadiums, screened globally on pay-TV networks, and marketed towards new middle-class consumerist lifestyles.

Importantly, these are not uniform and unstoppable processes; instead, they tend to be created, experienced, and adopted in complex, uneven, varied, and often contested ways, depending on context. In this regard, we might note two additional processes: reflexivization, which points to more reflective and critical engagement of audiences with global sport and consumer culture (Numerato, 2015, 2018); and, in turn, politicization, which involves some audiences moving into political actions, protests and campaigns on specific issues within global sport or consumer culture (Harvey et al., 2009; Scherer and Jackson, 2008; Wilson, 2007).

These five large-scale processes, and the two additional processes, provide the core structures through which global consumer sport is played out in more substantive terms.

\section{Substantive Themes}

Here, we identify seven major substantive features within the interface of global sport and consumer culture, and which are consistently referenced in different ways within this special issue.

First, as noted through our three-phase model, we have the long historical ties between global sport and consumer culture. While having certainly intensified over the past two or three decades, these bonds extend at least as far back as the late $19^{\text {th }}$ century with the establishment of many modern sports. 
Second, we have witnessed the intensified mutual interpenetration of global sport and consumer culture (Andrews and Clift, 2015; Crawford, 2004; Horne, 2006). This interpenetration has two broad dimensions. On one hand, there has been a consumerization of global sport, illustrated in how global sport tournaments are imbued with consumerist images, particularly in advertising products, and how sport apparel and equipment (such as football club shirts and baseball caps) have become everyday consumer items that are sold worldwide. On the other hand, the expanding sportization of consumer culture points to how wider areas of consumer culture -such as in media, technology, fashion, music, cuisine, and automobileshave featured increasing levels of sport content, for example in product adverts that include sport themes and endorsements.

Third, social structures and divisions shape and mediate social relationships to global consumer sport (Horne, 2006). Social class, gender, ethnicity, age or generation, and (dis)ability represent the main forces here, in influencing or determining the access and the 'tastes' of different social groups for different aspects of global consumer sport. At transnational level, longstanding core-periphery divisions largely remain, as 'core' North American and European regions generate the wealthiest and most globalized sport clubs, leagues, and products, while 'peripheral' African, Asian, and Latin American societies provide cheap, skilled labour (top athletes) and growing consumer marketplaces for sportrelated products (Rowe and Gilmour, 2010). Yet, since the late 1990s, some new geographies of consumption have emerged, as some non-core nations - China, India, Russia, the Gulf States - have cultivated successful sport leagues, recruited global sport stars, hosted global sport events, and provided flourishing venues for sport-related consumption (Brannagan and Giulianotti, 2015; Rumford, 2007).

Fourth, celebrity culture has intensified, as more of the world's leading athletes multiply their in-play earnings through commercial work as brand signs and endorsement vehicles (Andrews and Jackson 2001; Smart 2005). Sport corporations, clubs and leagues are heavily marketed through association with sport stars - think Jordan and Nike, Ronaldo and Real Madrid, or MLB and the NBA with a full array of globally-sourced talent. Contemporary social media platforms now enable sport stars to communicate directly with fans and followers, and thus to build more defined and detailed brand identities. New types of sport celebrity have emerged through the global rise of heavily commercialized lifestyle and e-sports.

Fifth, there is the making of global sport consumers to consider. The 'seduction industries' in advertising and marketing labour to stir, to shape, and to direct audience desires into 
consuming global sport-related products, from baseball caps to e-sport games. For consumers, an 'appetite' for global sport products becomes normalized, and, for those in smaller nations or more peripheral regions, may offer a sense of membership or a 'way into' transnational sport. Latterly, two distinctive sport identities have also emerged. On one hand, global sport prosumers are both consumers and, at times, producers of products, often through the guidance of advertising and marketing personnel - consider, for example, fans inside stadiums who produce choreographed, televised spectacles that attract other stadium fans and armchair viewers (cf. Ritzer and Jurgenson, 2010). On the other hand, global sport citimers combine varied mixes of 'citizen' and 'consumer' identity; following Parker's (1999) perspective, we may note that in some cases these citimers are socially-aware consumers who challenge different kinds of discrimination or intolerance within sport, human rights, ethics, as well as the issue of environmental sustainability.

Sixth, the glocal aspects of global consumer sport are evidenced in the mutual interdependence and interplay of the local and the global. Initially applied in business and marketing contexts, the theory of glocalization points to how global products and services are adapted to bed into local or national conditions (Robertson, 1992). Glocalization also points to how local and national societies, even peripheral ones, engage critically and selectively with global consumer sport (Giulianotti and Robertson, 2007). Thus, 'glocal' consumer sport is made by different social groups in how, for example, they embrace, adapt or eschew specific types of sport-related apparel such as baseball caps, or how sport tournaments in India or England carry strong local influences while also pulling in global sport stars, corporate sponsors, and television audiences.

Seventh, the politics of sport consumption have intensified within global sport. There are two sides to this theme. On one hand, the bottom-up politicization of consumerism within global sport is driven by greater consumer knowledge and critical reflexivity. This politicization can take place in sport, when related to sport spectator protests against the costs of event tickets or club merchandise, or through sport, when related to global social justice, ethical and human rights campaigning (e.g. Harvey, Horne, and Safai 2009). On the other hand, the more topdown consumerization of sport politics is reflected in how private corporations - particularly media and sponsors - exert influence over the management of sport federations, tournaments, and clubs. The darkest sides here are found in corrupt relationships that may arise between sport and private corporation officials (Numerato and Baglioni, 2012; Sugden and Tomlinson, 2016). 
While of course not excluding other themes, topics and issues that are also addressed by our contributors, these seven substantive themes stand out for us in different ways in the seven papers within this special issue. We turn now to outline briefly the contents of these papers.

\section{Contents}

Our opening paper, by the sociologist Barry Smart, examines the deep historical ties and complex interconnections between global sport and consumer culture through a discussion of Olympic sport. Smart argues that the values of modern Olympism, advocated by its founder Baron Pierre de Coubertin in the late $19^{\text {th }}$ century, have been remorselessly eroded by the professionalization and commercialization of elite-level sport. Key developments here include the growing involvement of corporate sponsors, the move towards profit-orientated Olympics since the 1984 event in Los Angeles, the greater production and marketing of Olympic-related merchandise, and the growing prominence of major sport brands such as Adidas, Nike and Puma in and around the Games. To illuminate these processes, Smart examines how three iconic black, male Olympic athletes - Jesse Owens, Carl Lewis and Usain Bolt - were deeply embedded within the consumer cultures of their times.

We turn next to explore how some everyday items of sport equipment and merchandise become inextricably tied to global consumer cultures. The anthropologist William Kelly examines the case of the baseball cap which, like blue jeans and running shoes, has gone from practical clothing to global fashion essential. At the same time, the baseball cap's global diffusion has been complex, culturally contingent, and subject to all manner of creative activity. As the 'millinery of late modernity', the versatile cap is worn to celebrate or to hide different identities; to operate across different fashion systems and social environments, and to afford anonymity on 'bad hair days'. Kelly notes that in some national contexts, such as Japan or Cuba, the cap is not widely worn due to underlying cultural or political reasons. In the sport itself, the cap's different usages and meanings help to differentiate stadium audiences: 'spectators' wear caps to signify team allegiances, while more committed 'fans' deploy this headwear as part of their repertoires of performance, in the endeavour to influence the game.

In global sport, several non-core nations have sought to develop their own heavily commercialized and successful sport tournaments. The Indian Premier League (IPL) is one such case, rapidly becoming the world's most lucrative cricket tournament, with short-format, spectacular matches that are wrapped in consumerist entertainment. Habibul Haque 
Khondker and Roland Robertson explain how the IPL has been substantially driven by profound changes within India, notably rapid economic growth, urbanization, and global commercial and cultural influences. They utilize Robertson's theory of 'glocalization' to capture the complex interplays of local and global dynamics within the IPL, for example as matches are contested by Indian and global cricket stars, and by teams owned by Indian celebrities and corporate leaders, while off-field music, cheerleading and other entertainment blends Indian and more global content. The IPL is itself marketed glocally, to the burgeoning urban consumerist Indian middle-classes, and to global cricket and sporting audiences.

The paper by Holly Thorpe and Kim Toffoletti turns attention to how contemporary social media, gender politics and celebrity culture interconnect within global consumer sport. They focus specifically on how five female global sport stars engage with, and are represented through, the major social media platform, Instagram. Partly by drawing on feedback from their fans, the athletes construct popular online 'brand' identities, which largely connect with dominant neoliberal and gender-based values such as personal responsibility, active consumerism, and 'hetero-sexy' femininity. At the same time, athletes pass on a controlled set of 'personal intimacies' which attract fan interest and appreciation. Overall, these social media sites demonstrate how conventional 'gendered regimes of visibility' continue to dominate how celebrity athletes are portrayed to global consumer audiences.

We move next to two papers that explore the interrelations of international football fans with global sport and consumer culture. Drawing on critical perspectives from sociology, marketing, and sport studies, the paper by Guillaume Bodet, Jamie Kenyon and Alain Ferrand examines how European football fans assess the growing consumer culture and processes of commercialization that surround their national football team and football associations. Their analysis centres on research undertaken across England, Lithuania, and Armenia - thereby capturing core and peripheral national fan experiences - while also registering the perspectives of 'die-hard' and more 'casual' supporters. In significant contrast to other research and analysis on football fans, the authors found relatively little fan opposition or resistance towards marketization processes; indeed, an underlying appetite for commercial branding was discerned among some East European fans. Future work in this area, as the authors argue, would do well to explore both the possibility of greater fan opposition to these commercial processes, or the influence of the relative marginality of some football teams in shaping supporter attitudes. 
The paper by Dino Numerato and Richard Giulianotti develops the concept of the 'citimer' to explore how citizen and consumer (or customer) identities come together within global sport, with a particular focus on fan movements within football. In broad terms, citimers are reflexive, socially aware and, often, politically active 'citizens' within sport; they are also, inevitably, 'consumers' of commercialized sport, whether as match spectators, television viewers or, for many, buyers of sport-related merchandise. Utilizing research with fan groups in England, Italy and the Czech Republic, the authors argue that citimer sport identities are constructed in two different yet deeply entangled ways. First, grassroots or 'bottom-up' citimer identities lean more on the social democratic, citizen role, and are constructed by fan groups and sports communities themselves, for example within autonomous supporter networks, associations, movements, and campaign groups. Second, more co-opted and 'topdown' identities put greater emphasis on neo-liberal, consumerist roles, and are largely moulded by more powerful organizations within football, such as governing bodies and elite clubs, which for example view meetings with supporter movements as exercises in 'customer relations'. Overall, football provides a powerful study-site for examining how citimer identities and practices are constructed and contested within contemporary cultural industries.

Our final paper, by David Andrews and George Ritzer, examines how, in sport, the breaking down of some boundaries between producer and consumer, or between production and consumption, serves to create sport 'prosumers' and 'prosumption'. Drawing on Toffler's (1980) path-breaking concept of 'prosumption', and its highly influential development by Ritzer and Jurgenson (2010), the authors explore in particular how sport consumers particularly spectators and sport media users - are also engaged in production, usually in ways that favour deeper commercial forces and interests. For example, sport fans produce entertaining or spectacular stadium atmospheres, often in ways that are orchestrated by sport marketing officials and commercial media stations, to increase the value of their sport 'product'. Social media and e-sports are further, contemporary spaces for prosumption, where sport fans are both consumers (accessing media content, buying gaming products) and producers (adding content to social media, making the action in e-sport games). Andrews and Ritzer are realistic on the future prospects for prosumption: prosumers may exercise creativity and critical agency in their productive activities, but they are also eased into unpaid labour in ways that largely sustain and extend the global commercial sport system.

\section{Notes}

1) For a wider application of Robertson's model to sport, see Giulianotti \& Robertson (2009). 
2) These latter points on phase 3.0 point to the possible argument that a post-Millennial phase 4.0, from the year 2000 onwards, might be identified, which is centred on the impacts within sport of contemporary globalization, digital mediatization, and the commercial development of urban centres in the global South.

\section{References}

Andrews DL and Clift BC (2015) Consumption and sport. In: The Wiley Blackwell Encyclopedia of Consumption and Consumer Studies, Oxford, UK: John Wiley \& Sons.

Andrews DL and Jackson SJ (2001) Sport Stars: The Cultural Politics of Sporting Celebrity. London: Routledge.

Boyle R and Haynes R (2009) Power Play: Sport, the Media and Popular Culture. Edinburgh: Edinburgh University Press.

Brannagan PM and Giulianotti R (2015) Soft power and soft disempowerment: Qatar, global sport and football's 2022 World Cup finals. Leisure Studies, 34(6): 703-719.

Crawford G (2004) Consuming Sport: Fans, Sport and Culture. London: Routledge.

Giulianotti R (2015) Sport: A Critical Sociology. Second Edition, Cambridge: Polity Press.

Giulianotti R and Klauser F (2009) Security governance and sport mega-events: Toward an interdisciplinary research agenda. Journal of Sport \& Social Issues 34(1): 49-61.

Giulianotti R and Robertson R (2007) Recovering the social: globalization, football and transnationalism. Global Networks, 7(2): 166-186.

Giulianotti R and Robertson R (2009) Globalization and football. London: Sage.

Harvey J, Horne J and Safai P (2009) Alterglobalization, global social movements, and the possibility of political transformation through sport. Sociology of Sport Journal 26(3): $383-403$.

Horne J (2006) Sport in Consumer Culture. London: Palgrave Macmillan.

Huggins M (2008) Sport and the British upper classes c. 1500-2000: A historiographic overview. Sport in History, 28(3): 364-388.

Hutchins B and Rowe D (2012) Sport beyond television: The internet, digital media and the 
rise of networked media sport. London: Routledge

Jenny SE, Manning RD, Keiper MC, et al. (2017) Virtual(ly) Athletes: Where eSports Fit Within the Definition of 'Sport'. Quest, 69(1): 1-18.

Lupton D (2016) The Quantified Self. Cambridge: Policy Press.

Numerato D (2015) Who says 'No to modern football?' Italian supporters, reflexivity, and neo-liberalism. Journal of Sport \& Social Issues 39(2): 120-138.

Numerato D (2018) Football Fans, Activism and Social Change. London: Routledge.

Numerato D and Baglioni S (2012) The dark side of social capital: An ethnography of sport governance. International Review for the Sociology of Sport 47(5): 594-611.

Parker G (1999) The role of the consumer-citizen in environmental protest in the 1990s. Space and Polity 3(1): 67-83.

Ritzer G and Jurgenson N (2010) Production, consumption, prosumption: The nature of capitalism in the age of the digital 'prosumer'. Journal of Consumer Culture 10(1): 1336.

Robertson R (1992) Globalization: Social Theory and Global Culture. London: Sage.

Rowe D and Gilmour C (2010) Sport, media, and consumption in Asia: A merchandised milieu. American Behavioral Scientist, 53(10): 1530-1548.

Rumford C (2007) More than a game: globalization and the post-Westernization of world cricket. Global Networks, 7(2): 202-214.

Sassatelli R (2004) The political morality of food: Discourses, contestation, and alternative consumption. In: Harvey M, McMeekin A, and Warde A (eds), Qualities of food, Manchester: Manchester University Press, pp. 176-191.

Scherer J and Jackson SJ (2008) Cultural studies and the circuit of culture: Advertising, promotional culture and the New Zealand All Blacks. Cultural Studies $<=>$ Critical Methodologies 8(4): 507-526.

Smart B (2005) The Sport Star. London: Sage.

Stranger M (2017) Surfing Life: Surface, Substructure and the Commodification of the Sublime. London: Routledge. 
Sugden J and Tomlinson A (2016) Football, Corruption and Lies: Revisiting 'Badfellas', the Book FIFA tried to ban. London: Routledge.

Thorpe H and Wheaton B (2011) 'Generation X Games', Action sports and the Olympic movement: Understanding the cultural politics of incorporation. Sociology 45(5): 830 847.

Toffler A (1980) The Third Wave. London: Collins.

Walsh AJ and Giulianotti R (2007) Ethics, Money and Sport: This Sporting Mammon. London: Routledge.

Wheaton B and Beal B (2003) 'Keeping It Real': Subcultural Media and the Discourses of Authenticity in Alternative Sport. International Review for the Sociology of Sport 38(2): $155-176$.

Wilson B (2007) New media, social movements, and global sport studies: A revolutionary moment and the sociology of sport. Sociology of Sport Journal 24(4): 457-477.

Witkowski E (2012) On the digital playing field. Games and Culture, 7(5): 349-374. 